\title{
THE RELATIONSHIP BETWEEN ISLAMIC CULTURAL VALUES AND CORPORATE SOCIAL ACCOUNTABILITY: MALAYSIAN MUSLIM ACCOUNTANTS
}

\author{
MOHAMMED SALEM ALAZZABI \\ MOHAMAD HISYAM SELAMAT \\ UUM College of Business \\ Universiti Utara Malaysia
}

\begin{abstract}
This study investigates the relationship between Islamic cultural values and corporate social accountability among Muslim accountants in Malaysia.Two independent variables are proposed namely collectivism and power distance. Multivariate analysis was employed to examine the relationship between the variables in the framework and 124 respondents participated in this study. It is found that there is no relationship between collectivism and corporate social accountability. On the other hand, there is a significant positive relationship between power distance and corporate social accountability. In conclusion this study recommends that the understanding on zakat and equality should be given utmost priority in order to increase the level of social accountability among Muslim accountants in Malaysia. Such learning activities should be given continuous professional development (CPD) point by the Malaysian Institute of Accountants (MIA) as a motivation.
\end{abstract}

Keywords: Islamic culture, collectivism, power distance, corporate social accountability.

\section{Introduction}

Hofstede (1980) defines culture as the collective programming of the mind which distinguishes the members of one group from another. It is often cited as a significant environmental factor that would possibly affect the accounting system and practices as well as the perception and use of accounting information by individuals (Palau, 2001). This is because accounting is seen as an interactive socio-technical activity involving both human and non-human resources or techniques and hence accounting cannot be cultural free (Violet, 1983). Increasingly, therefore, culture is often included as a possible barrier in the accounting harmonization process (Hamid, Craig \& Clarke, 1993; Palau, 2001).

Religion has been identified as one of the elements that influences cultural environment and in turn accounting practices (Briston, 1978; Baydoun \& Willett, 1995). This is because religion affects the way in which people behave and thus affects cultural values (Hamid et al., 1993). Interestingly, the focus has been on Islam, which is considered as ad-din wa al-Duniya or 'both faith and a way of life' (Abdullah, 1999). Islam is said to significantly influence accounting practices (Gambling \& Karim, 1991; Hamid et al., 1993; Karim, 1995; Baydoun \& Willett, 1995). This is because Islam prescribes a broad framework for its followers in all aspects of life including the manner as to how a business should be conducted (Baydoun \& Willett, 1995). Gambling and Karim (1986) support the stance that Islam is significantly influencing social accountability in countries where Islam is the official religion. Therefore it is interesting to study how Islam influences cultural values and 
in turn corporate social accountability among Muslim accountants in Malaysia.

To recapitulate, the purpose of this study is to investigate the relationship between Islamic cultural values and corporate social accountability among Muslim accountants. This study has a potential to enable the organizations to run their business activities according to Islamic norms and principles and shape attitudes and behaviours of the professionals in the near future.

To familiarize the reader with this paper, a description of its structure is provided. The paper begins by offering an examination of the elements of culture, social accountability, collectivism and power distance. These elements are then surveyed for specific guidance in relation to Islamic cultural values, and a framework synthesizing prior research is developed and presented. Following this, the research methodology is outlined, which then leads to a discussion of the findings. The paper then finishes with the conclusion and suggestion for future research.

$\sqrt{10}$

\section{Literature Review}

There are underpinning concepts that can be employed to understand how Islamic cultural values can be used to develop corporate social accountability among Muslim accountants. The following subsections provide this.

\section{The Conceptual Development of Culture}

There is no overall consensus on the precise meaning of culture (Seymour-Smith, 1986). Soeters and Schreuder (1988) state that there are as many definitions of culture as there are authors writing on the subject. The classical definition of culture, as noted in Violet (1983), is learned behaviour. Tylor (1929), considered by many to be the founder of modern anthropology, regards culture as knowledge, belief, art, morals, law, custom, and any other capabilities and habits that are acquired by man as a member of society.
Reviewing the anthropological work on culture, Violet $(1983$, p.3) defines culture as an “... integrated system of learned behaviour patterns that are characteristic of the members of a society and that are not the result of biological inheritance. Culture is therefore acquired behaviour. But it is as much a part of the natural universe as the stars in the heavens, for it is a natural product of man's activities, and man is part of nature." Culture is therefore viewed as the system which encompasses and determines the evolution of social institutions, social phenomena and mankind, enabling mankind to interpret and explain the immediate surrounding social phenomena (Verma \& Gray, 1997). Postulates or values of a culture determine a systematic choice by a society for explaining and rationalizing social phenomena and based on these postulates customs are created and adopted (Verma \& Gray, 1997). These customs themselves develop into or exist as social institutions. Accounting is argued to be one of such social institutions and as such must reflect the postulates of its culture. Violet (1983) concluded that each culture produces unique accounting structures shaped by a multitude of cultural constraints and variables which needed investigation.

There are several studies that examine the role of religion in dictating culture such as organizational cultures, micro-organizational behaviour, accounting environment and cognitive functioning of individuals (e.g. Gerhady, 1990; Baydoun \& Willett, 1995). The most prominent study is Gray (1988). He proposes a framework that relates religion to the accounting system. Thus it is argued that there is a close relationship between culture and religion.

Faruqi (1989) contends that religion is the very essence and core of culture. However, religion is a complex notion and is difficult to define (Acquaviva, 1979; Clark, 1958). Geertz (1973, p.90) defines religion as a system of symbols which acts to establish powerful, pervasive, and long-lasting moods and motivations in men by formulating conceptions of a general order of existence and clothing these conceptions with 
such an aura of factuality that the moods and motivations seem uniquely realistic.

Spiro and D'Andrade (1958) define religion as an institution consisting of a culturally-patterned interaction that shifts the concept of religion from a concern with psychological questions of belief to a focus on cultural actions, patterned by a world view, and reflected in rituals. Similarly, the main sociological theories of religion emphasize its role as a variable that offers a socially shared set of meanings (Askary, 2004). Religious behaviour, beliefs and experiences are simply part of the culture, and are regularly transmitted from generation to generation in the same way as any other custom (Argyle \& BeitHallahmi, 1975).

(1) Acquaviva (1979) argues that religion has always exerted a profound influence on many aspects of human life and personality. Every society has a religious dimension, which it shares and expresses in all aspects of the social life of individuals - their laws, their customs and habits (Gilkey, 1981). In fact, it has been proposed that capitalism owes its beginnings to the Protestant ethic, which emphasizes frugality and industry (Weber, 1985). According to Faruqi (1989), religion is the lens through which all understanding and thinking take place, making it the foundation of all decisions and actions. As such, religious ideas and practices have always been at the centre of human activities.

- From the aforementioned discussion it is clear that religion has a potential to affect social accountability and in turn accounting practice through the way institutions are organized and the processes they use (Baydoun \& Willet, 1995). This is because religion is the very essence and core of a culture (Faruqi, 1989).

\section{Toward Islamic Corporate Social Accountability}

Shahul (2000) defines accountability as "the duty to provide an account (by no means necessarily a financial account) or reckoning of those actions for which one is held responsible". The concept of accountability in Islam is coined as "hesab". Askary and Clarke (1997) observe that the word "hesab" is repeated more than eight times in different verses in the Koran. Hesab or account is the root of accounting (Shahul, 2000). In the Koran it refers to one's obligation to God in all endeavours.

Accountability is the duty of an entity to use (and prevent the misuse of) the entrusted resources in an effective, efficient and economical manner, within the boundaries of the moral and legal framework of the society, and to provide an account of its actions to accountees who are not only the persons who provided it with its financial resources but to groups within the society and to society at large (Shahul, 2000). Gray (1988) has used the accountability model as a theoretical framework forcorporate social and environmental reporting and mainly examined disclosures in annual reports and social/environmental audits. The accountability framework, however, is a much broader concept, which can explain the workings of accounting systems in their organizational contexts. According to Roberts and Scapens (1985), it may help to integrate the technical and interpersonal aspects of accounting systems by focusing on accounting practices and the human/organization/system and manager/ subordinate interface.

Lewis (2001) also observes that the basic similarity between "hesab" in Islam and accountability lies in the responsibility of every Muslim to carry out duties as prescribed in the Koran. Similarly, in business enterprises, both management and providers of capital are accountable for their actions in both within and outside the firm. Accountability in this context means accountability to the community (umma) or society at large. Hence, one would rationalize that the main objective of Islamic accounting would be to provide information that enables those involved in the firm to fulfil their accountability to society. Social responsibility would include charities, wages to employees, and environmental protection. This means that 
financial reporting in the Islamic society is likely to be more detailed than what is currently prevalent in Western societies.

From the above discussion it is clear that Islam can be used as a means to increase accountability awareness among accountants and promote transparent financial reporting. As this research is concerned with cultural issues, the discussion focuses on Islamic cultural values. Two Islamic cultural values are proposed which are collectivistic societies and small power distance. Both cultural values are selected because of their strong relationship with corporate social accountability (Askary, 2004).

\section{Collectivistic Societies}

A collectivistic society is the first element of this research conceptual framework. The view of collectivistic societies is in tandem with the Islamic view of unity that treats all Muslims as one national or ummah. Thus all Muslims are considered as one unified nation. The Koran declares:

-

All people are a single nation... (2:213). Verily, this nation of yours constitutes one nation, and I am your God, be cautious of me $(23: 52)$.

From the above verses it is clear that the Islamic society has to be considered as collectivist. In addition to this, however, Islam also recognizes the importance of an individual and greatly respects individual human rights. Islam preserves the importance of individual human rights and the virtues of self-reliance and personal independence. In this respect the Holy book says:

Whoever slays a soul, unless it is for manslaughter or for mischief in the land, it is as though he slew all men; and whoever keeps it alive, it is as though he kept alive all men... (5: 32)

Regarding Muslims as individuals is recommended by the Shariah (Islamic rules and regulations).
Thus, Islam addresses both the affairs of separate individuals and the society to which they belong. Nevertheless the ultimate focus is Muslim as one nation. The right of the Muslim society is much more important than the individual Muslim. What is good for the ummah is always good for the individual Muslim. The element of collectivistic society can be explained in five subelements as follows: (a) Brotherhood relationship, (b) Group management, (c) Collective interest, (d) Consensus in decision making, and (e) The role of the government (Askary, 2004).

\section{Brotherhood Relationship}

The holy Koran has placed great emphasis on the concept of unity (tawhid). This concept extends to all aspects of the life of the Islamic society. It directs the followers to be united as one society, with a strong networking relationship between each other. There are, therefore, specific orders to encourage, maintain and support genuine brotherly relations. These are supported by the following verse:

The believers are but brethren, therefore make peace between your brethren and be careful of (your duty to) Allah that mercy may be had on you (49:10).

The above verse is further supported by the following hadith. Prophet Muhammad (P.B.U.H.) said: "You will not enter Paradise until you have faith, and you will not have faith until you love each other. Shall I direct you to something which if you fulfil you will love one another? Spread peace among yourselves." (Muslim).

In the above hadith, our beloved Prophet (P.B.U.H.) recommends Muslims to spread peace. This can be fulfilled by saying peace be with you and by promoting peace in the society through reconciling differences. This is the slogan of Islam, namely, spreading peace. The word "Islam" indeed means peace and thus brotherhood is of paramount importance in Islam. 
Brotherhood relationship is further emphasized by the Messenger of Allah (P.B.U.H.) in hadith: "Don't belittle any good deed even to meet your brothers with a smiling face." He also said: "Smiling to your brothers is an act of charity." That is why the Messenger (P.B.U.H.) had a smiling face all the time. In short an individual Muslim should be smiling when meeting other Muslim brothers.

Thus, from the Islamic viewpoint, brotherhood relationship functions as a cultural network in which each person is responsible for the others a key characteristic of collectivistic societies. It is argued that accountants with strong brotherhood feelings are more accountable and thus always keep public interest in check. Thus, it is included in this research conceptual framework.

\section{Group Management}

The Calipha or leader is technically the manager of all Muslims. In the Koran it is mentioned that:

Oh who believe! Obey Allah, and obey the Messenger and those charged with authority among you (4:59).

The command of Allah, written in the Koran and manifested in Prophet Muhammad's (P.B.U.H.) deeds, should be obeyed without any variation or modification by Muslims. The Calipha or leader is responsible for administering that obedience. It has been commanded in the above verse that the Calipha (and all surrogates of Islamic authority) should be obeyed by Muslims after Prophet Muhammad (P.B.U.H.).

This order places all Muslims in an equal manner in respect to the administration of daily affairs and in respect to the access to legitimate authority of Allah through the Calipha. This can be interpreted as an emphasis in Islam on, at the end of the day, the potential of group (collectivistic) management. It is argued that a high degree of group management results in a high degree of accountability among accountants. Thus it is included in this research conceptual framework.

\section{Collective Interests}

The focus of the Koran is on the interests of the Muslim society as a whole rather than on the special interest of the individual Muslim. This is a common theme as indicated by the following verse:

And hold fast, all together, by the Convenient of Allah (habl-Allah) and be not split up among yourselves $(3: 102)$.

The Hofstede (1980) collectivist value corresponds, in sentiment, to the collectivistic (unity) value in Islam. Islam encourages its followers to be united. Every Muslim is responsible for the safety and well-being of other Muslims. Nevertheless, the government must play an active role in establishing a good Islamic society. The only permitted way for one Muslim to be more superior than the others is through knowledge, spiritual refinement, and obedience to Islamic laws.

From the aforementioned discussion it is clear that a high awareness of collective interests can increase accountability among accountants. Thus it is included in this research conceptual framework.

\section{Consensus in Decision-Making}

There is considerable evidence from early Islamic historical sources that Prophet Muhammad (P.B.U.H.) asked his followers to give opinions during critical situations such as holy wars. God commanded the Prophet, despite his unique position as the last messenger, to consult with his followers when administering the state. The Koran directs this value in the following verses:

... And consult with them upon the conduct of affairs (3:159)

...Who (conduct) their affairs (or, government) by mutual consultation... (42:38) 
Unquestionably, this is supportive to collectivistic values. In other words, the willingness to have a consensus in the meeting represents a high degree of collective interests. It is argued that the value of consensus in decision-making can influence accountability among accountants and as a consequence is included in this research conceptual framework.

\section{The Role of the Government}

The government is responsible for observing and enforcing Shariah law by developing and sustaining a welfare society. Therefore, the government has a dominant role in developing a robust economic system to sustain that necessary welfare framework (Askary, 2004). The Koran conveys the indisputable responsibility of the government in seemingly intractable situations:

....and discuss in deliberation with them (the professional Muslim) the governmental affairs thereupon, whenever you decide then (carry out your decision and) place your confidence and trust in God, verily God loves those who are trusting Him (3:159)

The above verse supports Gambling and Karim's (1986) description of the Islamic society as "the collective personalities..." (p.39) and Hofstede's (1980) subvalues of group societies. The Islamic society is thus expected to incline more towards a collectivist rather than an individualist society. This scenario leads to a high level of - accountability. To appreciate this, the element of government is included in this research conceptual framework.

\section{Small-Power-Distance}

This element represents the second element of this research conceptual framework. According to Hofstede (1980), power distance measures the degree of inequality in power within different classes of a society. Islamic societal values are conducive to (in Hofstedian terms) smallpower-distance classification. This matter is verified by small-power-distance-like criteria in the framework of the Koranic verses. This framework can be categorized into three categories as follows: (a) Absolute obedience to Allah, (b) The concept of equality, and (3) Zakat.

\section{Absolute Obedience to Allah}

In the Islamic religious philosophy, the only authorized legitimate, ultimate power belongs to Allah. Only Allah has absolute power and is the omnipotent force in the world. It is mentioned in the Koran that the believers should:

Fear of Allah and seek the means of approach unto Him and strive with might and main in his cause; that you may prosper (5:38).

O you who believe! Obey Allah and obey the Apostle and those in authority from among you (4:59).

Because Allah desires happiness for human life, the Islamic holy writ explains that He sent Muhammad (P.B.U.H.) and other Prophets before him (such as Jesus and Moses) to teach His laws. Thus, the only legitimate form of power in Islam is the one that complies with Shariah. As a consequence, the followers have to obey Shariah at all times. In the Koran Allah states:

And those saved from the desire of their own souls (i.e. those who rise above personal interests) they are the ones that attain felicity (64:16).

From the aforementioned discussion it is clear that Islam promotes absolute obedience to Allah and in turn low power-distance. It is argued that low power-distance leads to a high level of accountability. Therefore the element of absolute obedience to Allah is included in this research conceptual framework.

\section{Concept of Equality}

Islam desires neither a superior (first or affluent) class nor a poor class in its society. A middle 
or sustainable uniform class is most desired in Islam. This philosophy draws on brotherhood and justice. These are supported by the following verse:

The believers are but a single Brotherhood. Therefore, establish happiness, peace and order among two (contending) members of your brotherhood, and observe your duty to Allah that hopefully you may obtain mercy (49:10)

Equality in Islam implies that any individual should not enjoy a priority due to his/her race, language, colour, wealth or other distinguishing differences. In the Islamic philosophy, all people have equal rights in essential matters such as freedom, cultural justice and others. Islam provides sound laws to prevent and discourage all exploitation of the weak, injustice to the unprotected and expels despotism from society (Askary, 2004). Islam promotes the value of piety, truth, justice, love, wisdom, beauty, and selflessness, and thereby eliminates the emergence of a class-conflict society that inhibits human unity. The following verse addresses equality:

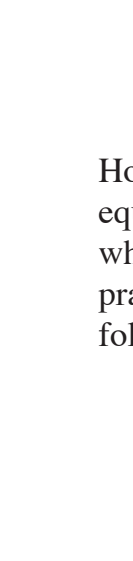

...And they have rights similar to those against them in a just manner... (2:228)

However, Islamic law does not entail absolute equality for human beings, especially for those who have a greater knowledge of Islam and practice Islamic virtues. This is evident from the following verse:

...Say: Are they equal - who know and those who do not know? Only those who are highly rational recognize (this fact) (39:9)

Consistent with the Islamic concept of the brotherhood of believers, one can conclude that the members of a Islamic society would be undifferentiated or class-equal group. Common status is the objective in Islam. Hofstede's (1980) middle-class conveys the idea of a dominant group of equal status - a somewhat similar notion. It is argued that a good Muslim accountant will observe class-equal group concept and as a consequence influences his accountability. Thus the element of equality is included in this research conceptual framework.

\section{Zakat}

Islam has provided a cultural welfare tax system through zakat for ensuring that the basic needs of the unfortunate Muslim are met. The Koran emphasizes that: "zakat is for the poor, the needy... a duty ordained by Allah... (9:60)." Literally, zakat means to grow (in goodness) or increase, purify or make pure. Thus, the act of giving zakat means the act of purifying one's wealth to gain Allah's blessing and to make it grow in goodness.

The rich are commanded to assist the needy by paying zakat and sadaqah (donation) so that the poor will not feel disregarded and isolated. The rich should not also offend the poor by their condescending behaviour. This rule applies equally to those who have authority in the government and the ordinary people (Askary, 2004). In summary, the Koran commands all believers to be benevolent to the weak and the poor through the exhortation that:

Make yourself submissively gentle to them with compassion... (17:24)

Muhammad is the Apostle of Allah, and those with him are firm of heart against the unbelievers, compassionate among themselves (48:24)

In short, zakat is not a sacrifice but a normal religious act. It is a trust from Allah (33:728). Islam therefore commands generosity in terms of voluntary economic well-doing to those in need and to the utmost of one's capacity. In other words, a Muslim must regard zakat as the fulfillment of the other is person's right not merely as a ritualistic religious charity to a beggar. Thus the accountants who believe in zakat are more accountable than those who are not. This will lead to the increase of the level of accountability. For this reason the element of zakat is included in this research conceptual framework. 


\section{Theoretical Basis}

To link the above theoretical information, a From the above conceptual framework, ten diagram of this research conceptual framework is outlined. The diagram is illustrated in Figure 1. hypotheses are proposed. All these hypotheses are illustrated in Table 1.

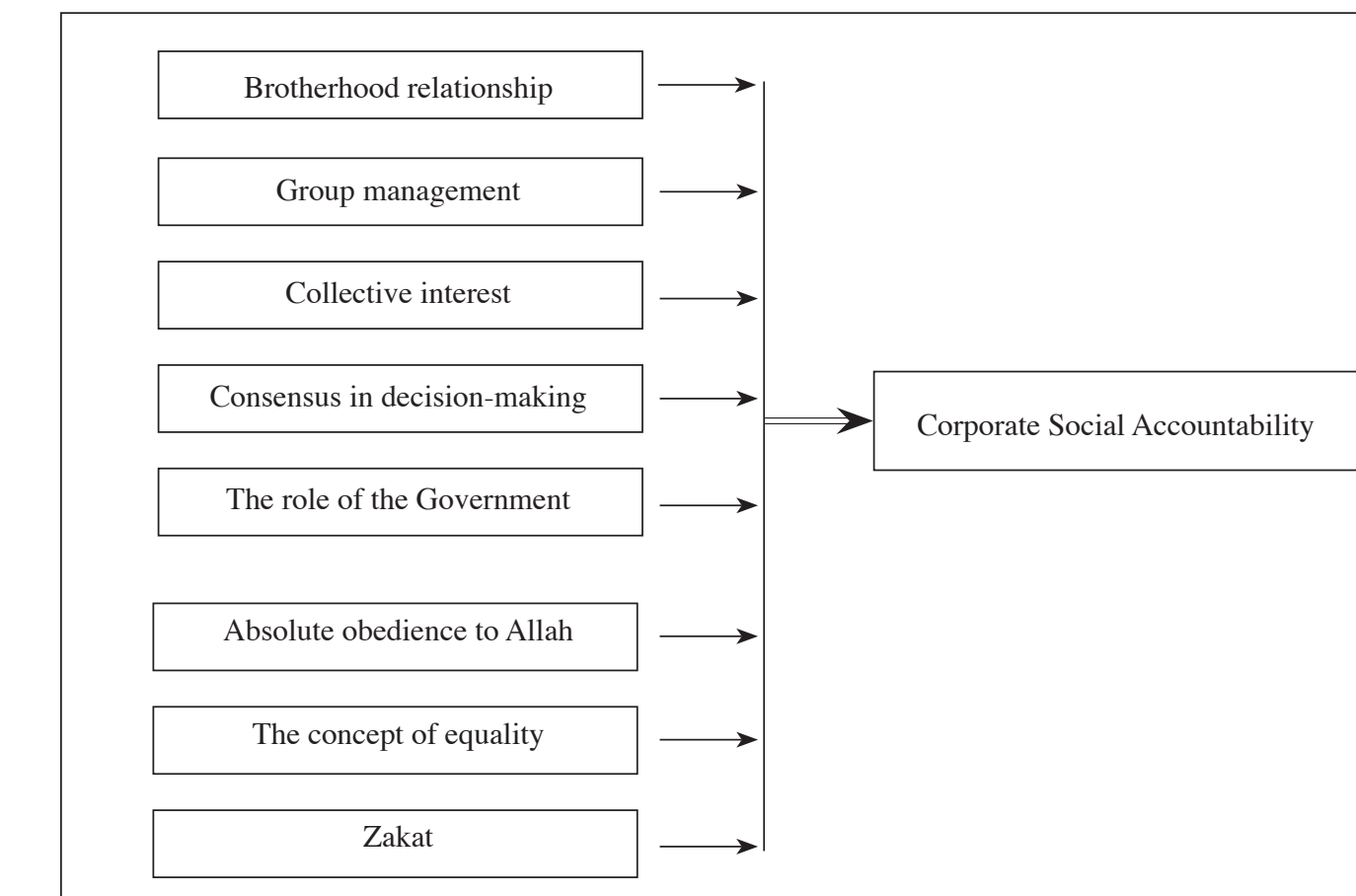

Figure 1. Conceptual framework.

Table 1

Research Hypotheses

Hypothesis Description

H1 There is a positive relationship between collectivism and corporate social accountability.

H1a There is a positive relationship between brotherhood relationship and corporate social accountability.

H1b There is a positive relationship between group management and corporate social accountability.

H1c There is a positive relationship between collective interest and corporate social accountability. 


\begin{tabular}{ll}
\hline Hypothesis & Description \\
\hline H1d & $\begin{array}{l}\text { There is a positive relationship between consensus in decision-making and corporate social } \\
\text { accountability. }\end{array}$ \\
H1e & $\begin{array}{l}\text { There is a positive relationship between the role of the government and corporate social } \\
\text { accountability. }\end{array}$ \\
H2 & There is a positive relationship between power-distance and corporate social accountability. \\
H2a & $\begin{array}{l}\text { There is a positive relationship between absolute obedience and corporate social } \\
\text { accountability. }\end{array}$ \\
H2b & There is a positive relationship between equality and corporate social accountability. \\
H2c & There is a positive relationship between zakat and corporate social accountability. \\
\hline
\end{tabular}

\section{Research Methodology}

(1) The survey method was utilized for this study. A self-administered questionnaire comprised the primary survey instrument for data collection, since it addressed the issue of reliability of information by reducing and eliminating differences in the way that the questions were asked, and how they were presented (Fowler, 2002). Furthermore, questionnaires facilitate the collection of data within a short period of time from the majority of respondents, which was a significant issue for this research (Fowler, 2002). Keeping the above in mind, multiple and closed questions were mainly included in the questionnaire. The literature review provided an initial understanding of Islamic cultural values and the basis for the development of a draft questionnaire. The eventual questionnaire consisted of a total of 10 questions. All 10 questions were close-ended, multiple, or Likertscale type in nature. From the 10, two questions were Likert-scale type that consisted of 66 subquestions or items. The total number of items for each construct is presented in Table 3. However, due to space limitation these items are not described in the paper, however, interested readers can find them from the original source, Alazzabi (2009). All the 66 Likert-scale type questions/items were adapted from Hofstede (1980) (cultural values) and Lewis (2001) (social accountability). Although the adapted questions were rigorously validated in source studies, we conducted a reliability test to confirm whether the adapted measures were internally consistent. The findings on this are presented in Table 3.

The sample of this study consisted of Malaysian Muslims employed as Chartered Accountants. The population consisted of Malaysian Muslim audit firms registered with the Malaysian Institute of Accountants. There are 1373 audit firms in Malaysia (Malaysian Institute of Accountants Members Directory, 2007). From this figure, 200 audit firms are considered as Muslim audit firms. The selection is based on the name of the audit firms. Using the systematic sampling technique, we selected a sample of 132 audit firms by considering every second firm from the sample frame (emulated Sekaran, 2003). The questionnaire was sent to the Chartered Accountant of each of the selected audit firms. The questionnaire was administered either as an email attachment or via postal service between August and November 2008. 124 usable questionnaires were returned within the specified time, resulting in a $62 \%$ response rate.

The initial stage of data analysis involved checking the responses and providing a unique identification number to each response. Using the SPSS (version 14), the research generated the descriptive statistics (i.e. frequencies, percentages and tables), and reliability tests, factor analysis and regression analysis were 
conducted to analyse and present the research findings.

\section{Findings}

\section{Demographic Analysis}

Table 2 presents the demographic profile of the survey respondents. Of the 124 responses received, 54\% were in the 25-34 year-old age group, which formed the largest response category. The 35-44 year-old age group was the next largest $(23.4 \%)$. In terms of gender, more male than female respondents $(\mathrm{m}=58.1 \%$, $\mathrm{f}=41.9 \%$ ) participated in the survey (Table 2). All respondents possessed educational qualifications, with $86.3 \%$ having undergraduate degrees and $4.8 \%$ educated to masters/ postgraduate level. $8.9 \%$ of the respondents reported other educational qualifications (Table 2). $70.2 \%$ of the respondents have been involved in the accounting field for more than 4 years and the remaining $29.8 \%$ have $1-3$ years of experience. Of the 124 respondents, only 54.8 per cent possessed professional qualification and the remaining 45.2 per cent did not have professional qualification (Table 2).

\section{Table 2}

Demographic Information of the Survey Respondents

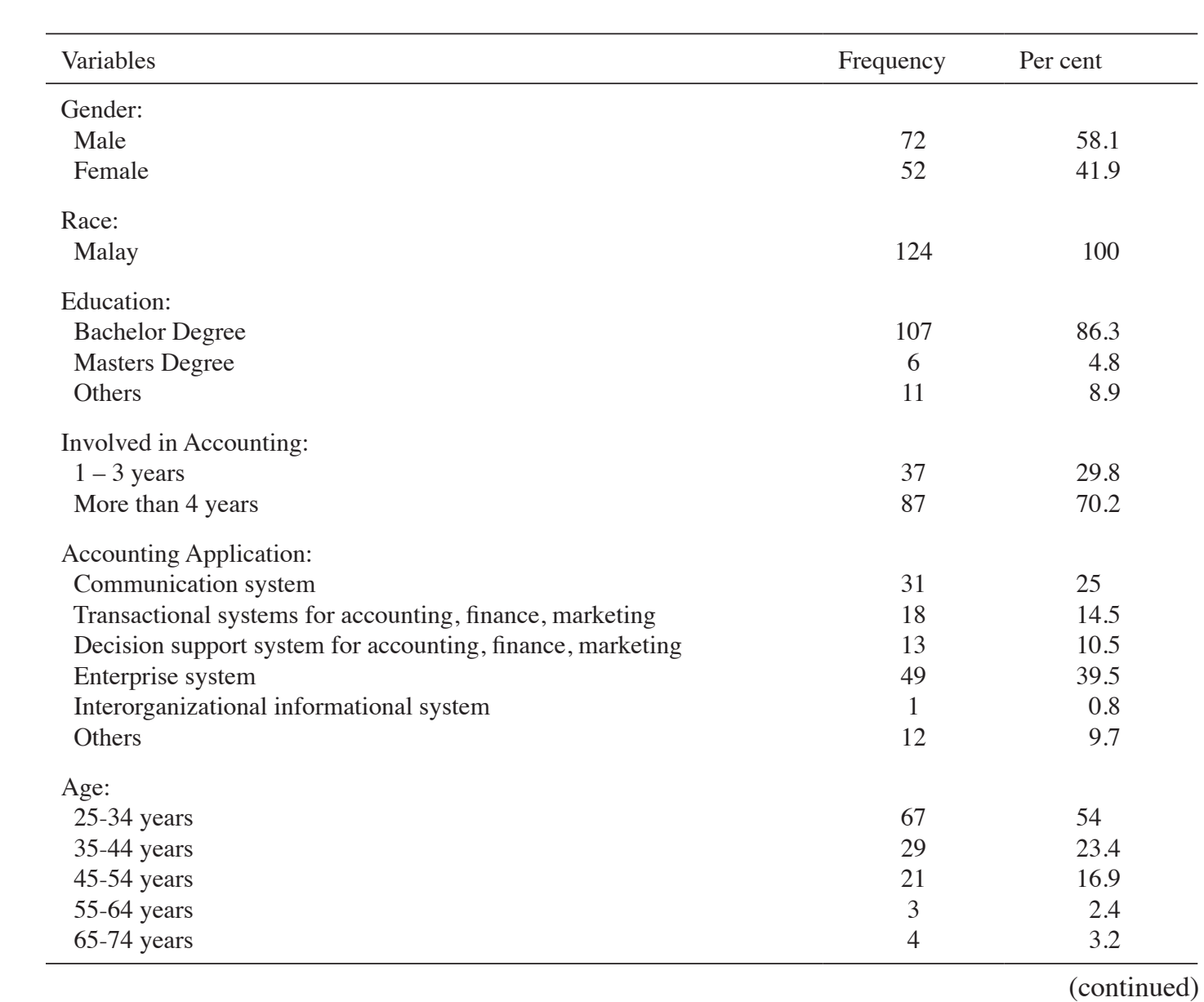




\begin{tabular}{lcc}
\hline Variables & Frequency & Per cent \\
\hline Professional Qualification: & & \\
No & 68 & 54.8 \\
Yes & 56 & 45.2 \\
Department: & & \\
Audit & 120 & 96.8 \\
Others & 4 & 3.2 \\
\hline
\end{tabular}

\section{Reliability Test}

Table 3 illustrates the Cronbach's coefficient alpha values that were estimated to examine the internal consistency of 0.94 for the corporate social accountability construct. Both group management and zakat possessed a reliability value of 0.94 . The Cronbach's coefficient alpha values for the remaining constructs are illustrated in Table 3. Hinton, Brownlow, McMurray, and Cozens (2004) have suggested four cut-off points for reliability, which includes excellent reliability ( 0.90 and above), high reliability ( 0.70 $0.90)$, moderate reliability $(0.50-0.70)$ and low reliability (0.50 and below) (Hinton et al., 2004, pp 364). The aforementioned values suggest that of the nine constructs, six possess excellent reliability and the remaining four illustrate high reliability. None of the constructs demonstrated a moderate or low reliability (Table 3 ). The high Cronbach's $\alpha$ values for all constructs imply that they are internally consistent. That means all the items of each construct are measuring the same content universe (i.e. construct). For example, all the ten items of corporate social accountability are measuring the same content universe of corporate social accountability. Similarly, all the seven items of group management are measuring the content universe of group management construct. In brief, the higher the Cronbach's value of a construct, the higher the reliability is of measuring the same construct.

Table 3

Reliability of Measurements

\begin{tabular}{lcccl} 
Constructs & $\mathrm{N}$ & $\begin{array}{c}\text { Number of } \\
\text { Items }\end{array}$ & $\begin{array}{c}\text { Cronbach's } \\
\text { Alpha }(\alpha)\end{array}$ & \multicolumn{1}{c}{ Type } \\
\hline Corporate Social Accountability & 124 & 10 & 0.94 & Excellent Reliability \\
Brotherhood & 124 & 7 & 0.93 & Excellent Reliability \\
Group Management & 124 & 7 & 0.94 & Excellent Reliability \\
Collective Interest & 124 & 7 & 0.81 & High Reliability \\
Consensus in Decision-making & 124 & 7 & 0.93 & Excellent Reliability \\
The Role of the Government & 124 & 7 & 0.84 & High Reliability \\
Absolute Obedience to Allah & 124 & 7 & 0.92 & Excellent Reliability \\
Equality & 124 & 7 & 0.87 & High Reliability \\
Zakat & 124 & 7 & 0.94 & Excellent Reliability \\
LEGEND: N= Sample Size & & & & \\
\hline
\end{tabular}




\section{Multiple Regression Analysis}

Multipleregressions were undertakentodetermine the impact of the elements of collectivism and power distance on social accountability. The result of multiple regression analysis revealed that there was no positive relationship between collectivism and corporate social accountability and therefore $\mathrm{H} 1$ was rejected. On the other hand, there was a positive relationship between power distance (equality and zakat) and corporate social accountability. Therefore $\mathrm{H} 2$ was accepted. All these information can be obtained in Table 4. By obtaining these results, this research was able to answer the research question and in turn the research objective.

Table 4

Summary of Hypothesis Testing Results

\begin{tabular}{|c|c|c|c|c|}
\hline 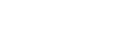 & Hypothesis Statement & $\operatorname{Adj} R^{2}$ & Sig. Level & Description \\
\hline H1a: & $\begin{array}{l}\text { There is a positive relationship between brotherhood } \\
\text { relationship and corporate social accountability. }\end{array}$ & $-0.01 \%$ & 0.597 & Rejected \\
\hline H1b: & $\begin{array}{l}\text { There is a positive relationship between group } \\
\text { management and corporate social accountability. }\end{array}$ & $-0.02 \%$ & 0.679 & Rejected \\
\hline H1c: & $\begin{array}{l}\text { There is a positive relationship between collective } \\
\text { interest and corporate social accountability. }\end{array}$ & $-0.02 \%$ & 0.705 & Rejected \\
\hline H1d: & $\begin{array}{l}\text { There is a positive relationship between consensus in } \\
\text { decision-making and corporate social accountability. }\end{array}$ & $-0.02 \%$ & 0.649 & Rejected \\
\hline H1e: & $\begin{array}{l}\text { There is a positive relationship between the role of } \\
\text { the government and corporate social accountability. }\end{array}$ & $-0.02 \%$ & 0.705 & Rejected \\
\hline & $\begin{array}{l}\text { There is a positive relationship between absolute } \\
\text { obedience and corporate social accountability. }\end{array}$ & $0.02 \%$ & 0.744 & Rejected \\
\hline H2b: & $\begin{array}{l}\text { There is a positive relationship between equality and } \\
\text { corporate social accountability. }\end{array}$ & $50 \%$ & 0.000 & Accepted \\
\hline & $\begin{array}{l}\text { There is a positive relationship between zakat and } \\
\text { corporate social accountability. }\end{array}$ & $43 \%$ & 0.000 & Accepted \\
\hline H1: & $\begin{array}{l}\text { There is a positive relationship between collectivism } \\
\text { and corporate social accountability. }\end{array}$ & $-0.02 \%$ & 0.853 & Rejected \\
\hline & $\begin{array}{l}\text { There is a positive relationship between power } \\
\text { distance and corporate social accountability. }\end{array}$ & $29 \%$ & 0.000 & Accepted \\
\hline
\end{tabular}

\section{Discussion}

Through the testing of the relationship between Islamic cultural values (collectivism and power distance) and the corporate social accountability, it is found that the element of power distance (zakat and equality) is significantly related to corporate social accountability. On the other hand, the element of collectivism is not significantly related to corporate social accountability and thus rejected. Implicit in these findings is that the understanding on zakat and equality should be given utmost priority in order to increase the level of social accountability among Muslim accountants in Malaysia. This is because by increasing the awareness of the importance of 
helping the poor, Muslim accountants incline to be more sensitive to upholding and protecting public interest in daily activities. For example, due to public concern and care any sensitive issues and managerial irregularities will be reported to the board of directors for immediate remedy.

The emphasis on zakat and equality is in tandem with Shahul (2000) and Sulaiman and Willet (2003). Shahul (2000) stated that the emphasis on zakat and equality is considered logical because it is a prime Islamic socio-religious obligation and in turn could lead to the avoidance of cheating and window dressing. In addition to this, Sulaiman and Willet (2003) opined that the level of social accountability can be increased (based on Islamic Shariah) by instilling awareness on charities, fair wages among employees and environmental protection. Thus accounting bodies such as the Malaysian Institute of Accountants and government agencies should inculcate those two elements among accountants in order to increase their accountability.

As the term zakat is unique to Islam (has been described many times in the Koran), it could m be said that Islamic Shariah has a potential to promote corporate social accountability among accountants. Other proposed elements such as brotherhood relationship, group management, collective interest, consensus in decision-making and the role of the government could be argued as universal values (Hofstede, 1980). Their rejection could be due to the perceived similarity between Islamic values and universal values that the respondents have in their mindsets. The significant relationship between zakat and social accountability, however, could refute such a view. If the term used in the research is unique to Islam such as solat (pray), muamalat (Islamic business conduct) and muaasyarat (Islamic ways when living in the society), significant relationship between Islamic values and social accountability could be uncovered. These are future research areas that can be considered by the researchers. This statement was supported by Gray (1988), Faruqi (1989) and Lewis (2001) who contended that religion (especially Islam) is the very essence and core element that direct economic decisions (including financial reporting) toward truthful and reliable business conduct.

To recapitulate, it can be seen that Islamic cultural values can be used as a platform to increase social accountability among accountants. The Malaysian Institute of Accountants, as the accounting regulatory body in Malaysia, should consider informal learning on Islamic values as one of the continuous professional development activities and in turn give points to such learning. This could further promote a healthy business conduct in Malaysia.

\section{Conclusions}

This study examined the relationship between Islamic cultural values and corporate social accountability from the perspective of Malaysian Muslim accountants. This study gives a better understanding about the relationship between Islamic cultural values and corporate social accountability and in turn accounting practices. It is argued that corporate social accountability plays an important role in establishing a transparent and reliable accounting system. From the analysis it is found that the elements of zakat and equality have a significant relationship with corporate social accountability. Thus accounting bodies and government agencies should inculcate those two elements among accountants in order to increase their accountability. This study also concludes that an in-depth study on collectivism should be undertaken to investigate its insignificancy in corporate social accountability and in turn accounting practice.

\section{References}

Abdullah, K., (1999). National security and Malay unity: The issue of radical religious elements in Malaysia. Contemporary Southeast Asia, August, 2(2), 261.

Acquaviva, S. S. (1979). The decline of the sacred in industrial society. Oxford: Basil Blackwell (Translated by P. Lipscomb). 
Alazzabi, M. S. I. (2009). Islamic cultural values among Malaysian Muslim accountants and their influence on corporate social accountability (Unpublished doctoral dissertation). Universiti Utara Malaysia.

Argyle, M., \& Beit-Hallahmi, B. (1975). The social psychology of religion. London: Routledge and Kegan Paul.

Askary,S.(2004). The influence of Islamic culture on the accounting values and practices of Muslim countries (Unpublished doctoral dissertation). University of Newcastle, Newcastle, Australia.

Askary, S., \& Clarke, F. (1997). Accounting in the Koranic verses. Paper presented at the accounting, commerce and finance: The Islamic perspective international conference. University of Western Sydney: Macarthur.

Baydoun, N., \& Willert, R. (1995). Cultural relevance of western accounting systems to developing countries. Abacus, 31(1), March, 67-92.

Briston, R. J. (1978). The evolution of accounting in developing countries. International Journal of Accounting Education and Research, 14(1), 105-20.

Clark, W. H. (1958). The psychology of religion. New York: The MacMillan.

Faruqi, I. (1989). Toward a critical world theology. In Toward Islamization of knowledge (Series No.6). International Institute of Islamic Thought, Herndon, Virginia, USA.

Fowler, F. J. Jr. (2002). Survey research methods. London: Sage Publications.

Gambing, T. E., \& Karim, R. A. A. (1986). Islam and social accounting. Journal of Business Finance \& Accounting, 13(1), Spring, 39-50.

Gambling, T. E., \& Karim, R. A. A. (1991). Business and accounting ethics in Islam. London: Mansell.

Geertz, C. (1973). Religion as a cultural system. New York: Basic Books.

Gerhady, P. G. (1990). An evaluation of the role of culture in the development of accounting principles in West Germany. Accounting and Finance Research Paper,
90/2, The Flinders University of South Australia.

Gilkey, L. (1981). Society and the sacred. New York: Crossroad.

Gray, S. J. (1988). Towards a theory of cultural influence on the development of accounting system internationally. Abacus, 24(1), 12-17.

Hamid, S. F., Craig, R., \& Clarke, F. (1993). Religion: A confounding cultural element in the international harmonization of accounting? Abacus, 29(2), 131-148.

Hinton, P. R., Brownlow, C., McMurray, I., \& Cozens, B. (2004). SPSS explained. East Sussex, England: Routledge.

Hofstede, G. (1980). Culture consequences: International differences in work related values. California: Sage Publications.

Karim, R. A. A. (1995). The nature and rationale of a conceptual framework for financial reporting by Islamic banks. Accounting and Business Research, Autumn, 25(100), 285-300.

Lewis, M. K. (2001). Islam and accounting. USA: Blackwell Publishers.

Malaysian Institute of Accountants Directory. (2007). Malaysian Institute of Accountants. Kuala Lumpur.

Palau, S. L. (2001). Ethical evaluation, intentions and orientations of accountants: Evidence from a cross-cultural examination. International Advance in Economic Research, August, 7(3), 351-364.

Roberts, J., \& Scapens, R. (1985). Accounting systems and systems of accountability - understanding accounting practices in their organizational contexts. Accounting, Organizations and Society, 443-456.

Sekaran, U. (2003). Research methods for business: A skill-building approach (4th ed.). Singapore: John Wiley \& Sons.

Seymour-Smith,C.(1986). Macmillan dictionary of anthropology. London: Macmillan Press.

Soeters, J., \& Schreuder, H. (1988). The interaction between national and organizational cultures in accounting firms. Accounting, Organizations and Society, 13, 75-85. 
Shahul, Z. (2000). The future of Muslim civilization. London: Mansell Publishing.

Spiro, M. E., \& D'Andrade. (1958). A cross cultural study of some supernatural beliefs. American Anthropologist, 60, 456-466.

Sulaiman, M., \& Willet, R. (2003) Using the Hofstede-Gray framework to argue normatively for an extension of islamic corporate reports. Malaysian Accounting Review, 2(1), 1-39.

Tylor, E. B. (1929). Primitive culture. London: Murray.
Verma, S., \& Gray, S. (1997). The impact of culture on accounting development and change: An exploratory model. Paper presented at the international association for accounting education and research conference, Paris, October.

Violet, W. J. (1983). The development of international accounting standards: An anthropological perspective. The International Journal of Accounting, Spring, 1-12.

Weber, M. (1985). The protestant ethic and the spirit of capitalism. London: Unwin Paperbacks. 